\title{
HUBUNGAN KARAKTERISTI PASIEN, PERILKU BERSESIKO DAN IMS DENGAN KEJADIAN HIV/AIDS PADA WANITA USIA SUBUR DI KLINIK VCT UPT BLUD PUSKESMAS MENINTING TAHUN 2015-2017
}

\author{
RELATIONSHIP BETWEEN PATIENT CHARACTERISTICS, RISK \\ BEHAVIOR AND STIS WITH HIV / AIDS EVENTS IN FERTILE AGE \\ WOMEN IN VCT CLINICS UPT BLUD MENINTING HEALTH \\ CENTERS IN 2015-2017
}

\author{
Saembe Oktaseli, Mutiara Rachmawati, Ati Suliaty \\ Politeknik Kesehatan Kemenkes Mataram, Indonesia \\ Korespondensi: mutiara_rachmawati@poltekkesmataram.ac.id
}

\begin{abstract}
HIV / AIDS is one of the global health problems. All over the country is currently threatened with the spread of a deadly virus. Not only in developed countries, but also in developing countries like Indonesia, including in NTB. To determine the relationship of patient characteristics, risk behavior, STIs with HIVIAIDS events in reproductive-aged women in the UPT BLUD Meninting Health Center in 2015-2017. This research is observational analytic with a Case-control design. The population in this study were 312 women of childbearing age who came to HIV testing. The sampling technique uses simple random sampling so that the number of 42 cases of HIV positive and 270 HIV negative as control cases. Data analysis using univariate and bivariate. Of the 312 women of childbearing age who came for HIV testing, the variables associated with the incidence of HIV were age $(p=0.018)$, education $(p=0.011)$, employment $(p=0.026)$, marital status $(p=0.000)$, risky behavior $(p=0.000)$, and STI status (0.017). To prevent the occurrence of HIV, the authors suggest using condoms when doing risky sexual behavior, it is also recommended for STI examinations to prevent HIV transmission.
\end{abstract}

Keywords : Data on patient status in VCT clinics, women of childbearing age, HIV incidence

\begin{abstract}
ABSTRAK
HIV/AIDS merupakan salah satu masalah kesehatan global. Di seluruh negara saat ini sedang terancam dengan penyebaran virus yang mematikan. Tidak hanya di negara maju, tetapi juga di negara berkembang seperti Indonesia, termasuk di NTB. Penelitian ini Untuk mengetahuiHubunganKarakteristi Pasien, Perilaku Beresiko, IMS dengan Kejadian HIV/AIDS pada Wanita Usia Subur di UPT BLUD Puskesmas Meninting Tahun 2015-2017

Penelitian ini bersifat observasional analitik dengan desain Case control. Populasi dalam penelitian ini adalah seluruh wanita usia subur yang datang tes HIV sebanyak 312 orang. tehnik pengambilan sampel menggunakan simple rondom sampling sehingga jumlah sampel kasus 42 HIV positif dan 270 HIV negatif sebagai kasus kontrol. Analisis datamenggunakan univaria dan bivariat. Dari 312 wanitausiasubur yang datangtes HIV, variable yang berhubungandengan kejadian HIV adalah umur $(\mathrm{p}=0.018)$, pendidikan $(\mathrm{p}=0.011)$, pekerjaan $(\mathrm{p}=0.026)$, status kawin $(\mathrm{p}=0.000)$, perilaku beresiko $(\mathrm{p}=0.000)$, dan status IMS (0.017). Untuk mencegah terjadinya HIV, maka penulis menyarankan untuk mengunakan kondom pada saat melakukan prilaku seks beresiko, juga disarankan untuk pemeriksaan IMS untuk mencegah penularan HIV.
\end{abstract}

Kata Kunci : Data status pasien di klinik VCT, Wanita Usia Subur, Kejadian HIV 


\section{PENDAHULUAN}

Sejak kasus pertama kali di Indonesia terjadi pada tahun 1987, Provinsi pertama kali ditemukan adanya kasus HIV dan AIDS adalah di Provinsi Bali, sedangkan yang terakhir melaporkan adalah Provinsi Sulawesi Barat pada tahun 2011. Kejadia HIV/AIDS di Indonesia tahun 2015 meningkat pada tahun 2016. Pada tahun 2015 jumlah kejadian HIV sebanyak 30,935 kasus dan AIDS sebanyak 6,081 kasus dan meningkat pada tahun 2016 jumlah kejadian HIV menjadi 41,250 kasus dan AIDS menjadi 7,491 kasus dari diseluruh provinsi di Indonesia. Kejdian tertinggi HIV pada tahun 2016 adalah propinsi Jawa Tengan sebanyak 6.513 kasus, DKI Jakarta 6.019 kasus, Jawa Barat sebanyak 5.466 kasus dan yang terendah pada provinsi Gorontalo sebanyak 7 kasusu HIV (Data dan Informasi Profil Kesehatan RI, 2016).

Data kasus HIV/AIDS tahun 2016 di Indonesia yang terbanyak pada golongan usia 30-39 tahun (37\%), usia 20-29 tahun (27\%). Usia 40-49 (19\%), usia 50-59 tahun (8\%), usia >60 tahun (4\%), usia 1-19 tahun $(5 \%)$, usia $<1$ tahun $(0 \%)$. Pada kelompok jenis kelaminadalah pada laki-laki (68\%), perempuan (32\%). Pada kelompok pekerjaan, karyawan (722 kasus), supir ( 80 kasus), narapidana ( 16 kasus), PNS (99 kasus), tenaga medis ( 56 kasus), anak sekolah ( 91 kasus ), wiraswasta ( 757 kasus), petani, buruh (136 kasus ), IRT ( 618 kasus ). Sedangkan menurut faktor resiko, tidak diketahui (1\%), IDU (3\%), Heterosex (77\%), homosex (32\%), bisex $(0 \%)$, prinatal (4\%), lain lain(3\%)(Data dan Informasi Profil Kesehatan RI, 2016).

Di NTB jumlah kasus HIV terjadi penurunan pada tahun 2015 ke tahun 2016. Pada tahun 2015 kasus kejadian HIV terdapat 194 kasus dan pada tahun 2016 jumlah kasus HIV terdapat 175 kasus. Sedangkan kejadian AIDS pada tahun 2015 terdapat 89 kasus dan pada tahun 2016 terdapat 75 kasus. Jadi dari hasil data tahun 2015 sampai 2016 terjadi penurunan angka kejadian HIV/AIDS di NTB (Profil Kesehatan NTB, 2016 ).

Di wilayah Puskesmas Lombok Barat didapatkan jumlah kasus HIV terjadi peningkatan. Pada tahun 2015 kasus HIV sebanyak 78 kasus dan AIDS sebanyak 79 kasus, sedangankan pada tahun 2016 kejadian HIV sebanyak 93 kasus dan AIDS sebanyak 98 kasus. ( Data Profil Kesehatan Lombok Barat, 2016)

Data kasus HIV pada tahun 2015, terdapat pada golongan jenis kelamin, Perempuan sebanyak (40 orang), laki-laki (38 orang). Menurut pekerjaan, IRT (14 orang), karyawan swasta (8 orang), WPS (18 orang). Faktor resiko, heterosex (49 kasus), Homosex (68 kasus), ibu ke anak (3 
kasus), jarum suntik (6 kasus). Sedangkan pada tahun 2016, terdapat pada golongan jenis kelamin, Perempuan sebanyak (45 orang ), laki-laki (41 orang). Menurut pekerjaan, IRT(20 orang), karyawan swasta (19orang), WPS (24 orang). Faktor resiko, heterosex (59 kasus), Homosex (11kasus), ibu ke anak(3 ksus), jarum sunti (8 kasus). (Data Profil Kesehatan Lombok Barat,2016)

UPT BLUD Puskesmas Meninting merupakan pusat konseling HIV dari klinik VCT lainnya di NTB. Menurut data Puskesmas UPT BLUD Meninting kunjungan VCT dari tahun ke tahun terus meningkat pada tahun 2015 jumlah kunjungan pemeriksaan HIV/AIDS sebanyak 97 orang dengan positif HIV sebanyak 8 orang dan AIDS 3 orang,kasus Infeksi Menular Seksual (IMS) sebanyak 44 orang, kemudian meningkat pada tahun 2016 dengan jumlah kunjungan 117 orang dan yang mengalami positif HIV sebanyak 30 orang, AIDS 7 orang, Infeksi Menular Seksual (IMS) sebanyak 50 orang .(Rigeter Klini VCT UPT BLUD Puskesmas Meninting tahun 2016)

Faktor-faktor penyebab kejadian HIV yang berperan penting dalam pengaruh kejadian peningkatan dan penurunan HIV/AIDS di masyarakat. Berdasarkan Penelitian Eulis Mar'atul Kamila (2014) mengenai hubungan karakteristik pasien, perilaku beresiko, dan infeksi menular seksual dengan kejadian HIV/AIDS di Klinik VCT Puskesmas Cikarang, Kecamatan Cikarang Utara, Kabupaten Bekasi didapatkan hasil bahwa HIV/AIDS paling banyak terjadi pada usia produktif yang berkisar antara 20-24 tahun dengan persentase sebanyak 12,9\% dikarenakan faktor perilaku beresiko seperti berhubungan seksual yang tidak aman (Vaginal Seks) dan mengalami infeksi menular seksual (tidak datang memeriksa) sebanyak $22,2 \%$.

Sedangkan pada penelitian Tuti Suliawati, tahun 2014 faktor-fator beresiko dengan kejadian HIV dan AIDS. kasus HIV dan AID kejadiannya terbanyak pada golongan usia 21-30 tahun $(43,42 \%)$, dan usia $31-40$ tahun $(34,21 \%)$, kejadian HIV/AIDS pada tingkat pendidkan terbanyak pada perguruan tinggi $(68,42 \%)$, Sedangkan kejadian HIV/AIDS pada kasus PMS sebanyak (52,8\%), pada pengunaan nakoba jarum suntik $(8,2 \%)$.

Hal ini sesuai dengan laporan Kemenkes RI (2016) bahwa infeksi HIV/AIDS tertinggi khususnya pada wanita terjadi pada kelompok umur wanita usia subur yakni 15-49 tahun $(89,4 \%)$.

Konseling dan Testing Sukarela yang dikenal sebagai Voluntari Counselling and Testing (VCT) merupakan salah satu 
strategi kesehatan masyarakat dan sebagai pintu masuk ke seluruh layanan kesehatan HIV/AIDS berkelanjutan. Klinik VCT berfungsi unuk kegiatan konseling yang me nyediakan dukungan psikologis, informasi dan pengetaahuan HIV/AIDS, mencegah penularan HIV, mempromosikan perubahan perilaku yang bertanggung jawab, pengobatan ARV dan memastikan pencegahan masalah terkait dengan HIV/AIDS(Depkes RI,2008).

Di Indonsia jumlah klinik VCT pada tahun 2016 terdapat 3.204 klini VCT yang terdapat di beberapa provinsi yaitu dari 31 provinsi di Indonesia, salah satunya adalah provinsi NTB yang memiliki 25 Klini VCT (Kemenkes RI, 2016 )

Nusa Tenggara Baratmemiliki 25 klinik VCT yang bertujuan sebagai pencegahan penularan dan pengobatan HIV/AIDS, yaitu terdapat pada kabupaten Dompu 1 Klinik VCT, Kota Mataram 10 Klinik VCT, Lobar 1 Klinik VCT, Loteng 6 Klinik VCT, Lotim 7 Klinik VCT. (Dikes NTB, 2016)

Berdasarkan latar belakang masalah yang telah dipaparkan, maka penelitian tertarik meneliti hubungan karakteristik Pasien, perilaku berisiko dan infeksi menular seksual dengan kejadian HIV/AIDS pada wanita usia subur di klinik VCT UPT BLUD Puskesmas Meninting tahun 2015-2016.

\section{METODE}

Penelitian ini menggunakan penlitian observasional analitik dengan Casecontrol yang merupakan rancangan penelitian yang membandingkan antara kelompok kasus dengan kelompok kontrol untuk mengetahui proporsi kejadian berdasarkaan riwayat ada tidaknya paparan dengan cara melihat data register dan status kunjungan pasien yang melakukan tes HIV dan IMS di Klinik VCT UPT BLUD Puskesmas Meninting tahun 2015-2017 sebanyak 879 orang. Besar sampel yang digunakan sebanyak 42 HIV positif sebagai kasus dan 270 HIV negatif sebagai kontrol. Teknik pengambilan sampel kasus dan kontrol mengunakan simple rondom sampling. Penelitian mengunakan tingkat kemaknaan $\mathrm{P}=0,05$ yaitu Hasil pelrhitungan bila $p$ value lebih kecil dari $\alpha$ 0,05 maka $\mathrm{H}_{0}$ ditolak bila $p$ value lebih besar dari $\alpha$ 0,05 maka $\mathrm{H}_{0}$ diterima.

Variabel independen dalam penelitian ini adalah karakteristik pasien (umur, pendidikan, status perkawinan, pekerjaan), prilaku beresiko, infeksi menular seksual dan sbagai variabel dependen adalah kejadian HIV/AIDS pada wanita usia subur. Analisis univariat bertujuan untuk menjelaskan atau mendeskripsikan karakteristik setiap variabel penelitian. Sedangkan, Analisa Bivariate bertujuan 
untuk melihat hubungan antara variabel independen dan varabel dependen.

\section{HASIL DAN PEMBAHASAN}

Tabel 1. Pasien Berdasarkan Kejadian HIV pada Wanita Usia Subur di Klinik VCT UPT BLUD Puskesmas Meninting tahun 2015-2017

\begin{tabular}{lcc}
\hline Kejadian HIV & n & \% \\
\hline Positif & 42 & 13.5 \\
Negatif & 270 & 86.5 \\
\hline Total & 312 & 100.0 \\
\hline
\end{tabular}

Berdasarkan Tabel 1 menunjukkan bahwa dari 312 yang datang tes HIV di Klini VCT UPT BLUD Puskesmas Meniting pada tahun 2015-2017 sebesar 42 orang (13,5\%) HIV positif dan HIV negatif sebesar 270 orang $(86,5 \%)$

Tabel 2. Distribusi Frekuensi Usia Subur di Klinik VCT Karakteristik Umur Pasien Berdasarkan Kejadian HIV pada Wanita UPT BLUD Puskesmas Meninting tahun 2015-2017

\begin{tabular}{lcc}
\hline Umur Pasien & $\mathbf{N}$ & $\boldsymbol{\%}$ \\
\hline $15-19$ & 11 & 3.5 \\
$20-35$ & 220 & 70.5 \\
$36-49$ & 81 & 26.0 \\
\hline Total & 312 & 100.0 \\
\hline
\end{tabular}

Berdasarkan Tabel 2 menunjukkan bahwa data pasien yang datang tes HIV pada wanita usia subur di Klinik VCT UPT BLUD Puskesmas Meninting pada tahun 2015-2017 terbanyak pada umur 20-35 tahun sebanyak 220 orang $(70,5 \%)$, dan data pasien yang paling sedikit pada kelompok umur 15-19 tahun sebanyak 11 orang $(3.5 \%)$.

Tabel 3. Distribusi Frekuensi Karakteristik Pendidikan Pasien Berdasarkan Kejadian HIV pada Wanita Usia Subur di Klinik VCT UPT BLUD Puskesmas Meninting tahun 2015-2017

\begin{tabular}{lcc}
\hline $\begin{array}{l}\text { Pendidikan } \\
\text { pasien }\end{array}$ & N & \% \\
\hline Tidak Sekolah & 21 & 6.7 \\
SD & 56 & 17.9 \\
SMP & 90 & 28.8 \\
SMA & 125 & 40.1 \\
Perguruan Tinggi & 20 & 6.4 \\
\hline Total & 312 & 100.0 \\
\hline
\end{tabular}

Berdasarkan Tabel 3 menunjukkan bahwa pasien yang datang tes HIV pada wanita usia subur di Klinik VCT UPT BLUD Puskesmas Meninting pada tahun 2015-2017, data pendidikan pasien terakhir yang ditempuh oleh pasien yang paling terbanyak adalah kelompok pendidika SMA sebanyak 125 orang $(40,1 \%)$, dan data pendidikan yang terendah terdapat pada kelompok pendidikan perguruan tinggi sebanyak 20 orang $(6.4 \%)$. 
Tabel 4. Distribusi Frekuensi Karakteristik Pekerjaan Pasien Berdasarkan Kejadian HIV pada Wanita Usia Subur di Klinik VCT UPT BLUD Puskesmas Meninting tahun 2015-2017

\begin{tabular}{lcc}
\hline $\begin{array}{lcc}\text { Pekerjaan } \\
\text { Pasien }\end{array}$ & N & \% \\
\hline Tidak beresiko & 236 & 75.6 \\
Beresiko & 76 & 24.4 \\
\hline Total & 312 & 100.0 \\
\hline
\end{tabular}

Berdasarkan Tabel 4 menunjukkan bahwa pasien yang datang tes HIV pada wanita usia subur di Klinik VCT UPT BLUD Puskesmas Meninting pada tahun 2015-2017, Pada kelompok pekerjaan terbanyak pada pekerjaan tidak beresiko sebanyak 236 orang (75.6\%), dibandingkan dengan pekerjaan beresiko sebanyak 76 $(24.4 \%)$.

Tabel 5. Distribusi $\quad$ Frekuensi Karakteristik Status Perkawinan berdasarkan kejadian HIV paeda Wanita Usia Subur di Klinik VCT UPT BLUD Puskesmas Meninting tahun 2015-2017

\begin{tabular}{lcc}
\hline Status Perkawinan & N & \% \\
\hline Belum kawin & 28 & 9.0 \\
Kawin & 255 & 81.7 \\
Cerai & 29 & 9.3 \\
\hline Total & 312 & 100.0 \\
\hline
\end{tabular}

Berdasarkan Tabel 5 menunjukkan bahwa data status perkawinan pasien yang datang tes HIV pada wanita usia subur di
Klinik VCT UPT BLUD Puskesmas Meninting pada tahun 2015-2017 terbanyak pada kelompok status kawin sebanyak 255 orang $(81.7 \%)$, dan data status kawin paling sedikit pada status belum kawin sebanyak 28 orang $(9.0 \%)$.

Tabel 6. Distribusi Frekuensi Pasien Perilaku Beresiko Berdasarkan kejadian HIV pada Wanita Usia Subur di Klin VCT UPT BLUD Puskesmas Meninting Tahun 2015-2017

\begin{tabular}{lcc}
\hline Perilaku Beresiko & $\mathbf{N}$ & $\mathbf{\%}$ \\
\hline $\begin{array}{l}\text { Tidak melakukan } \\
\text { Hubungan sex tidak } \\
\text { terlindungi }\end{array}$ & 129 & 41.3 \\
$\begin{array}{l}\text { Hubungan sex tidak } \\
\text { aman }\end{array}$ & 35 & 11.2 \\
$\begin{array}{l}\text { Berganti-ganti } \\
\text { pasangan }\end{array}$ & 11 & 3.5 \\
$\begin{array}{l}\text { Berganti-ganti alat } \\
\text { suntik }\end{array}$ & 1 & 3 \\
\hline Total & 312 & 100.0 \\
\hline
\end{tabular}

Berdasarkan Tabel 6 dapat dilihat dari data pasien yang datang tes HIV di klinik VCT UPT BLUD Puskesmas Meninting pada tahun 2015-2017 yang melakukan perilaku beresiko paling banyak pada kelompok hubungan seks tidak terlindungi 136 orang (43.6\%), dan perilaku beresiko paling sedikit pada kelompok berganti alat suntik sebanyak 1 orang (3\%). 
Tabel 7. Distribusi Frekuensi Pasien Status IMS Berdasarkan Kejadian HIV pada Wanita Usia Subur di Klinik VCTUPT BLUD Puskesmas Meninting Tahun 2015-2017

\begin{tabular}{lcc}
\hline Status IMS & N & \% \\
\hline IMS & 140 & 44.9 \\
Tidak IMS & 172 & 55.1 \\
\hline Total & 312 & 100.0 \\
\hline
\end{tabular}

Berdasarkan Tabel 7 menunjukkan bahwa data status IMS pasien yang datang tes HIV pada wanita usia subur di Klinik VCT UPT BLUD Puskesmas Meninting pada tahun 2015-2017 data Status pasien IMS terbanyak pada golongan yang mengalami IMS sebanyak 140 orang (44,9\%). Dibandingkan dengan yang tidak mengalami IMS sebanyak $172(55.1 \%)$.

Tabel 8. Analisis Hubungan Karakteristik Umur Pasien dengan Kejadian HIV pada Wanita Usia Subur di Klinik VCT UPT BLUD Puskesmas Meninting Tahun 2015-2017

\begin{tabular}{|c|c|c|c|c|c|c|c|}
\hline \multicolumn{3}{|c|}{ Karakteristik } & \multicolumn{3}{|c|}{ Kejadian HIV } & \multirow{2}{*}{\multicolumn{2}{|c|}{ Total }} \\
\hline & & & Positif & \multicolumn{2}{|c|}{ Negatif } & & \\
\hline Umur & $\mathbf{N}$ & $\%$ & $\mathbf{n}$ & $\%$ & $\mathbf{N}$ & $\%$ & \\
\hline $15-19$ & 3 & 1.0 & 8 & 2.6 & 11 & 3.5 & 0.018 \\
\hline $20-35$ & 35 & 11.2 & 185 & 59.3 & 220 & 70.5 & \\
\hline $36-49$ & 4 & 1.3 & 77 & 24.7 & 81 & 26,0 & \\
\hline Total & 42 & 13.5 & 270 & 86.5 & 312 & 100.0 & \\
\hline
\end{tabular}

Berdasarkan Tabel 8, dari 312 orang yang datang tes HIV di klini VCT UPT
BLUD Puskesmas Meninting, hasil analisa didapatkan 42orang mengalami HIV positif dan mengalami HIV positif terbanyak pada umur 20-35 tahun sebanyak 35 orang (11.2\%), dan paling sedikit pada umur 1519 tahun sebanyak 3 orang (1.0\%). Sedangkan hasil pemeriksaan 270 orang HIV negatif dan terbanyak pada umur 20-35 tahun sebanyak 185 orang (59.3\%), dan terkecil pada umur 15-19 tahun sebanyak 8 orang $(2.6 \%)$.

Berdasarkan Uji Chi-Square menunjukkan hasil $p$ value $=0.018<0.05$, sehingga dapat disimpulkn bahwa, bahwa terdapat hubungan yang signifikan antara umurwanita usia subur dengan kejadian HIV.

Tabel 9. Analisis Hubungan Karakteristik Pendidikan dengan Kejadian HIV pada Wanita usia Subur di Klin VCT UPT BLUD Puskesmas Meninting Tahun 2015-2017

\begin{tabular}{|c|c|c|c|c|c|c|c|}
\hline \multirow{3}{*}{$\begin{array}{l}\text { Karakteristik } \\
\text { Pendidikan }\end{array}$} & \multicolumn{4}{|c|}{ Kejadian HIV } & \multirow{3}{*}{\multicolumn{3}{|c|}{$\begin{array}{c}P \\
\text { Value }\end{array}$}} \\
\hline & \multicolumn{2}{|c|}{ Positif } & \multicolumn{2}{|c|}{ Negatif } & & & \\
\hline & $\mathrm{N}$ & $\%$ & $\mathrm{~N}$ & $\%$ & & & \\
\hline Tidak Sekolah & 7 & 2.2 & 14 & 4.5 & 21 & 6.7 & 0.002 \\
\hline $\mathrm{SD}$ & 9 & 2.9 & 45 & 14.4 & 54 & 17.3 & \\
\hline SMP & 15 & 4.8 & 75 & 24.0 & 90 & 28.8 & \\
\hline SMA & 9 & 2.9 & 116 & 37.2 & 125 & 40.1 & \\
\hline $\begin{array}{l}\text { Perguruan } \\
\text { Tinggi }\end{array}$ & 2 & 6 & 20 & 6.4 & 22 & 7.1 & \\
\hline Total & 42 & 13.5 & 270 & 86.5 & 312 & 100.0 & \\
\hline
\end{tabular}


Berdasarkan Tabel 9, dari 312 orang yang datang tes HIV di klini VCT UPT BLUD Puskesmas Meninting, hasil analisa didapatkan 42 orang mengalami HIV positif dan terbanyak pada kelompok pendidikan SMP sebanyak 15 orang (4.8\%),dan terkecil pada pendidkan pergurua tinggi 2 orang (6\%). Sedangkan hasil pemeriksaan 270 orang HIV negatif dan terbanyak pada kelompok pendidikan SMA sebanyak 116 orang $(37.2 \%)$, dan yang terkecil pada pendidkan tidak sekolah sebanyak 14 orang $(4.5 \%)$

Berdasarkan Uji Chi-Square menunjukkan hasil $p$ value $=0.002<0.05$, sehingga dapat disimpulkn bahwa, bahwa terdapat hubungan yang signifikan antara pendidikan wanita usia subur dengan kejadian HIV.

Tabel 10. Analisis Hubungan Karakteristik Pekerjaan, dengan Kejadian HIV pada Wanita Usia Subur di Klin VCT UPT BLUD Puskesmas Meninting Tahun 2015-2017
Berdasarkan Tabel 10, dari 312 orang yang datang tes HIV di klini VCT UPT BLUD Puskesmas Meninting, hasil analisa didapatkan 42 orang mengalami HIV positif dan terbanyak pada kelompok tidak beresiko sebanyak 26 orang (8.3\%) dan terkecil pada kelompok beresiko sebanayak 16 orang (5.1\%). Sedangkan hasil pemeriksaan 270 orang HIV negatif dan terbanyak pada kelompok tidak beresiko sebanyak 210 orang (67.3\%) dan terkecil pada kelompok beresiko sebanayak 60 orang $(19.2 \%)$.

Berdasarkan Uji Chi-Square menunjukkan hasil $p$ value $=0.026<0.05$, sehingga dapat disimpulkn bahwa, bahwa terdapat hubungan yang signifikan antara pekerjaan wanita usia subur dengan kejadian HIV.

Tabel 11. Analisis Hubungan Status Perkawin dengan Kejadian HIV pada Wanita Usia Subur di Klin VCT UPT BLUD Puskesmas Meninting Tahun 2015-2017

\begin{tabular}{|c|c|c|c|c|c|c|c|}
\hline \multicolumn{2}{|c|}{ Karakteristik } & \multicolumn{4}{|c|}{ Kejadian HIV } & \multirow{2}{*}{\multicolumn{2}{|c|}{$\begin{array}{c}P \\
\text { Value }\end{array}$}} \\
\hline & & \multicolumn{2}{|c|}{ Positif } & \multicolumn{2}{|c|}{ Negatif } & & \\
\hline Pekerjaan & $\mathrm{N}$ & $\%$ & $\mathrm{~N}$ & $\%$ & $\mathrm{~N}$ & $\%$ & \\
\hline $\begin{array}{l}\text { Tidak } \\
\text { beresiko }\end{array}$ & 26 & 8.3 & 210 & 67.3 & 236 & 75.6 & 0.026 \\
\hline Beresiko & 16 & 5.1 & 60 & 19.2 & 76 & 24.4 & \\
\hline Total & 42 & 13.5 & 270 & 86.5 & 312 & 100.0 & \\
\hline
\end{tabular}

\begin{tabular}{|c|c|c|c|c|c|c|}
\hline \multirow[t]{2}{*}{ Karakteristik } & \multicolumn{3}{|c|}{ Kejadian HIV } & \multirow{2}{*}{\multicolumn{2}{|c|}{ Total }} & \multirow{3}{*}{$\begin{array}{l}P \\
\text { Value }\end{array}$} \\
\hline & Positif & & gatif & & & \\
\hline $\begin{array}{l}\text { Status } \\
\text { Perkawinan }\end{array}$ & $\mathrm{N} \%$ & $\mathrm{n}$ & $\%$ & $\mathrm{~N}$ & $\%$ & \\
\hline belum kawin & 92.9 & 19 & 6.1 & 28 & 9.0 & 0.000 \\
\hline Kawin & 237.4 & 232 & 74.4 & 255 & 81.7 & \\
\hline Cerai & 103.2 & 19 & 6.1 & 29 & 9.3 & \\
\hline Total & 4213.5 & 270 & 86.5 & 312 & 100.0 & \\
\hline
\end{tabular}


Berdasarkan Tabel 11, dari 312 orang yang datang tes HIV di klini VCT UPT BLUD Puskesmas Meninting, hasil analisa didapatkan 42 orang mengalami HIV positif dan terbanyak pada kelompok status kawin sebanyak 23 orang (7.4\%), dan terkecil pada status belum kawin sebanyak 9 orang (2.9\%). Sedangkan pada hasil pemeriksaan 270 orang menglami HIV negatif dan terbanyak pada kelompok status kawin sebanyak 232 orang (74.4\%), dan terkecil pada status cerai dan status belum kawin sebnyak 19 orang (6.1\%).

\section{Berdasarkan Uji Chi-Square} menunjukkan hasil $p$ value $=0.000<0.05$, sehingga dapat disimpulkn bahwa, terdapat hubungan yang signifikan antara status perkawinan wanita usia subur dengan kejadian HIV.

Tabel 12. Analisis Hubungan Perilaku Beresiko dengan Kejadian HIV pada Wanita Usia Subur di Klin VCT UPT BLUD Puskesmas Meninting Tahun 2015-2017

\begin{tabular}{|c|c|c|c|c|c|c|c|}
\hline \multirow{3}{*}{$\begin{array}{l}\text { Perilaku } \\
\text { Beresiko }\end{array}$} & \multicolumn{6}{|c|}{ Kejadian HIV } & \multirow{3}{*}{$\begin{array}{l}P \\
\text { Value }\end{array}$} \\
\hline & \multicolumn{2}{|c|}{ Positif } & \multicolumn{2}{|c|}{ Negatif } & \multicolumn{2}{|c|}{ Total } & \\
\hline & $\mathbf{N}$ & $\%$ & $\mathbf{N}$ & $\%$ & $\mathbf{N}$ & $\%$ & \\
\hline $\begin{array}{l}\text { Tidak } \\
\text { melakukan }\end{array}$ & 4 & 1.3 & 125 & 40.1 & 129 & 41.3 & 0.000 \\
\hline $\begin{array}{l}\text { Hubungan } \\
\text { Seks tidak } \\
\text { terlindungi }\end{array}$ & 19 & 6.1 & 117 & 37.5 & 136 & 43.6 & \\
\hline
\end{tabular}

\begin{tabular}{|c|c|c|c|c|c|c|}
\hline $\begin{array}{l}\text { Hubungan } \\
\text { seks tidak } \\
\text { aman }\end{array}$ & 12 & 3.8 & 23 & 7.4 & 35 & 11.2 \\
\hline $\begin{array}{l}\text { Berganti- } \\
\text { ganti } \\
\text { pasangan }\end{array}$ & 6 & 1.9 & 5 & 1.6 & 11 & 3.5 \\
\hline $\begin{array}{l}\text { Berganti- } \\
\text { ganti alat } \\
\text { suntik }\end{array}$ & 1 & 3 & 0 & 0 & 1 & 3 \\
\hline Total & 42 & 13.5 & 270 & 86.5 & 312 & 100.0 \\
\hline
\end{tabular}

Berdasarkan Tabel 12, dari 312 orang yang datang tes HIV di klini VCT UPT BLUD Puskesmas Meninting, hasil analisa didapatkan 42 orang mengalami HIV positif dan terbanyak pada kelompok perilaku beresiko hubungan seks tidak terlindungi sebanyak 19 orang $(6.1 \%)$, dan yang terkecil pada kelompok berganti-ganti alat suntik sebanyak 1 orang (2.4\%). Sedangkan pada hasil pemeriksaan 270 orang menglami HIV negatif dan perilaku beresiko terbanyak pada kelompok hubungan seks tidak terlinsungi sebanyak 117 orang $(37.5 \%)$, dan terkecil pada hubungan seks tidak aman sebanyak 23 orang $(7.4 \%)$.

\section{Berdasarkan Uji Chi-Square} menunjukkan hasil $p$ value $=0.000<0.05$, sehingga dapat disimpulkn bahwa, bahwa terdapat hubungan yang signifikan antara perilaku beresiko wanita usia subur dengan kejadian HIV. 
Tabel 13. Analisis Hubungan Status IMS dengan Kejadian HIVpada Wanita Usia Subur diKlin VCT UPT BLUD Puskesmas Meninting Tahun 2015-2017

\section{Kejadian HIV}

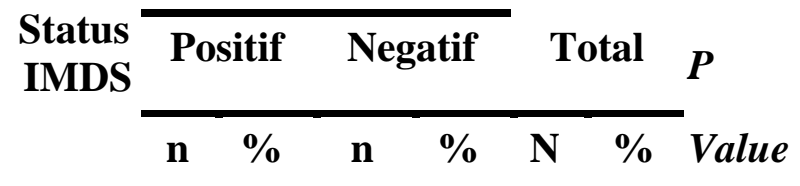

\begin{tabular}{llllllll}
\hline IMS & 26 & 8.3 & 114 & 36.5 & 140 & 44.9 & 0.017
\end{tabular}

Tidak $16 \quad 5.1 \quad 156 \quad 50.0$

IMS

\begin{tabular}{lllllll}
\hline Total & 42 & 13.5 & 270 & 86.5 & 312 & 100.0
\end{tabular}

Berdasarkan Tabel 13, dari 312 orang yang datang tes HIV di klini VCT UPT BLUD Puskesmas Meninting, hasil analisa didapatkan 42 orang mengalami HIV positif dan terbanyak pada kelompok IMS sebanyak 26 orang $(8.3 \%)$ dan tidak IMS sebnyak 16 orang $(5.1 \%)$. Sedangkan pada hasil pemeriksaan 270 orang mengalami HIV negatif dan mengalami IMS sebanyak 114 orang (36.5\%), dan tidak IMS sebanyak 156 orang (50.0\%).

\section{Berdasarkan Uji Chi-Square} menunjukkan hasil $p$ value $=0.017<0.05$, sehingga dapat disimpulkn bahwa, bahwa terdapat hubungan yang signifikan antara pendidikan wanita usia subur dengan kejadian HIV.
Berdasarkan hasil penelitian di atas maka peneliti akan membahas sesuai tujuan peneliti adalah sebagai berikut :

\section{Karakteristika pasien}

\section{a. Umur}

Terdapat

hasilpenelitian menunjukkan, dari data pasien yang datang tes HIV pada wanita usia subur di Klinik VCT UPT BLUD Puskesmas Meninting pada tahun 2015-2017 terbanyak pada umur 2035 tahun sebanyak 220 orang (70,5\%), dan data pasien yang paling sedikit pada kelompok umur 15-19 tahun sebanyak 11 orang (3.5\%).

Usia remaja dan usia produktif sangat beresiko terhadap penularan HIV/AIDS. Infeksi HIV/AIDS sebagian besar $(80 \%)$ diderita oleh kelompok usia produktif ( 25-44 tahun).

dilakukan oleh Eulis Mar Atul (2014). Hubungan Karakteristik Pasien, Perilaku Beresiko, dan IMS dengan Kejadian HIV/AIDS di Klini VCT Puskesmas Cikarang, Kecamatan Cikarang Utara, Kabupaten Bekasi tahun 2013. Dari hasil analisis bivariat dapat dilihat persentase pasien yang masuk kelompok umur $<20$ tahun dan mengalami kejadian HIV positif 
yaitu sebesar $12.1 \%$, sedangkan pasien dengan umur 20-24 tahun mengalami HIV positif sebanyak $12.9 \%$, umur 25-30 tahun yang mengalami kejadian HIV positif sebesar $13,8 \%$, dan umur > 20 tahun yang mengalami HIV positif sebesar $11.0 \%$.

\section{b. Pendidikan}

Terdapat hasil penelitian menunjukkan, dari 312 orang pasien yang datang tes HIV pada wanita usia subur di Klinik VCT UPT BLUD Puskesmas Meninting pada tahun 2015-2017, data pendidikan pasien terakhir yang ditempuh oleh pasien yang paling terbanyak adalah golongan pendidika SMA sebanyak 125 orang $(40,1 \%)$, dan data pendidikan yang terendah terdapat pada golongan pendidikan tidak sekolah sebanyak 21 orang (6.7\%).

Penelitian ini sama dengan hasil penelitian Fitri Handayani (2014). Dengan judul identivikasi perilaku seksual dengan kejdian HIV di kabupaten Sidoarjo. Hasil penelitiannya didapatkan hasil dalam kelompok pendidikan sedang sebanyak 47 responden $(58.5 \%)$, pada kelompok rendah sebanyak 17 responden $(20.7 \%)$, dan pada kelompok pendidikan tinggi sebanyak 13 responden (15.9\%),

Menurut anissa H. (2013), pendidikan menentukan bahwa seseorang yang berpendidikan tinggi akan lebih rendah keterentanannya terhadap resiko terinfeksi HIV dan AIDS dibandingkan mereka yang berpendidikan di sekolh rendah maupun putus sekolah.

\section{c. Pekerjaan}

Terdapat hasil penelitian menunjukkan, dari 312 pasien yang datang tes HIV pada wanita usia subur di Klinik VCT UPT BLUD Puskesmas Meninting pada tahun 2015-2017, Pada golongan pekerjaan terbanyak pada pekerjaan tidak beresiko sebanyak 236 orang (75.6\%), sedangkan pekerjaan beresiko sebanyak 76 (24.4\%).

Hasil penelitian ini sama dengan hasil penelitian Annisa (2014), tentang "Analisis Karakteristi dan FatorFaktor yang mempengaruhi Stigma Pengidap HIV (ODHIV) di Kota Yogyakarta. Dimana hasil penelitian terbanyak terjadi pada status Bekerja sebanyak 90.2\% dan tidak bekerja $9.8 \%$.

Dalam pekerjaan terdapat pekerjaan yang tidak bersiko dan beresiko. 
Pekerjaan yang tidak membawa resiko tinggi seperti ibu rumah tangga, pedagang, pengusahan, dan lain-lain. Sedangkan pekerjaan beresiko yang menyebabkan resiko tinggi penularan HIV/AIDS seperti, Wanita Pegawe Seksual, wanita penjaja seks, PSK, dan lain-lain (Meliyana,2014)

\section{d. Status perkawinan}

Terdapat hasil penelitian menunjukkan berdasarkan hasil penelitian yang dilakukan, dari 312 pasien yang datang tes HIV pada wanita usia subur di Klinik VCT UPT BLUD Puskesmas Meninting pada tahun 2015-2017 terbanyak pada kelompok status kawin sebanyak 255 orang (81.7\%), dan data status perkawinan paling sedikit dengan kelompok status status cerai sebanyak 29 orang $(9.0 \%)$ dan belum kawin sebanyak 28 orang $(9.0 \%)$

Hasil penelitian ini juga sejalan dengan hasil penelitian Darmawansyah (2011), tentang "Gambaran Kasus HIV/AIDS Pada Ibu Rumah Tangga". Didapatkan hubungan antara status perkawinan baik kawin maupun tidak kawin yakni sebanyak $(79,2 \%)$ dan $(53,7 \%)$ terhadap pemanfaatan klinik VCT pada kelompok berisiko.
Marum, et al. (2003) dalam tulisannya menyebutkan bahwa pajanan yang lebih sering dari suami terinfeksi HIV kepada istri yang berstatus HIV negatif yang ditularkan melalui hubungan seksual akan meningkatkan risiko istri terinfeksi HIV (Marum, et al., 2003).

Hal ini sesuai dengan teori bahwa ada hubungannya jumlah pasangan dengan kejadian HIV. Di mana semakin banyak pasangan seksual maka semakin banyak pula peluang tertularnya virus HIV dalam tubuh ke tubuh yang lain. Sehingga virus ini juga berdampak pada ibu rumah tangga yang memiliki suami dengan risiko tinggi. Sesuai dengan Depkes RI dalam laporan KPA (2008) bahwa Frekuensi melakukan hubungan seksual selain dengan istri atau kontak seksual komersial termasuk dalam perilaku berisiko. Semakin sering melakukan hubungan seksual dengan berganti pasangan akan memperbanyak peluang tertularnya virus dalam tubuh ke tubuh yang lain. Karena Virus HIV dapat ditularkan pada saat hubungan seksual.

\section{Perilaku beresiko}

Terdapat hasil penelitian menunjukkan berdasarkan hasil penelitian yang dilakukan, dari 312 pasien yang datang 
tes HIV pada wanita usia subur di Klinik VCT UPT BLUD Puskesmas Meninting pada tahun 2015-2017. Hasil analisa menunjukkan, dapat dilihat persentase perilaku beresiko pasien yang terbanyak pada kelompok hubungan seks tidak terlindungi sebanyak 136 orang (43.6\%) dan kecil pada kelompok berganti alat suntik sebanyak 1 orang (3\%). Dari hasil menujukkan presentase perilaku beresiko yang mengalami kejadian HIV/AIDS yang terbanyak dialami pada kelompok paien dengan perilaku hubungan seks tidak terlindungi dengan presentase sebanyak.

Perilaku beresiko terkena HIV/AIDS merupakan orang yang mempunyai kemungkinan terkena infeksi HIV/AIDS atau menularkan HIV/AIDS pada orang lain bila dia sendiri mengidap HIV/AIDS, karena prilakunya. Mereka yang memiliki prilaku beresiko tinggi adalah berganti-ganti pasangan, perempuan atau laki tuna susila, hubungan seks yang tidak wajar, Tidak menggunakan kondomMenggunakan narkotika, Homoseksual.

Berdasarkan distribusi prilaku seksual beresiko dilihat dari kebiasaan responden dengaan mengunakan kondom, salah satu penunggulangan HIV adalah pengupayakan peningkatan penggunaan kondom pada kegiatan seks beresiko mampu pencegahan penularan HIV, terlihat dari semakin rendah kasus penularan infeksi menular seksual termasuh HIV.

Hasil penelitian ini sama dengan penelitian yang dilakukan oleh Fufa Nandarasari (2012), tentang "Menunjukkan hasil penelitian responden yang tidak pernah menggunakan kondom ketika berhubungan dengan selain istri sebanyak 39 orang (62.9\%). Responden yang kadag-kadang mengunaan kondom ketika berhubungan dengan selain istri sebanyak 17 orang (27.4\%), responden yang selalu menggunakan kondom ketika berhubungan dengan selain istri sebanyak 6 orang $(9.7 \%)$.

\section{Status IMS}

Terdapat hasil penelitian menunjukkan berdasarkan hasil penelitian yang dilakukan, dari 312 pasien yang datang tes HIV pada wanita usia subur di Klinik VCT UPT BLUD Puskesmas Meninting pada tahun 2015-2017. Dari persentase pasien paling banyak kelompok IMS sebanyak 172 orang (55.1\%), Penelitian Eulis Maratun (2014). Dengan judul karakteritik pasien, perilaku beresiko, dan IMS dengan Kejadian HIV/AIDS di Puskesmas Cikarang, Kabupaten 
Cikarang Timur, Kabupaten Bekasi tahun 2013. Dari hasil penelitian menunjukkan bahwa didapatkan hasil pasien yang terjadi HIV positif IMS sebanyak 120 orang $(85.1 \%)$, sedangkan kejafdian HIV positif dengan IMS negatif lebih besar sebanyak 338 orang (90.4\%).

Penelitian ini sama dengan penelitin yang dilakukan Anissa (2014), tentang "Analisis Karakteristik Dan Faktor Yang Mempengaruhi Pengidap HIV Di Kota Yogyakarta". Dari hasil penelitian didapatkan IMS positif sebanayak 27 responden $(84.4 \%)$, sedangkan yang negatif sebanyak 5 responden $(15.6 \%)$.

Menurut Laksana 2010 peradangan pada ulkus pada penderita IMS meningkatkan kerentanan terhadap infeksi HIV, karena rusaknya barier mukosa memudahkan masuknya virus HIV ke dalam pembunuh darah. IMS bisanya tidak memiliki gejala terutama pada wanita sehingga kadang-kadang orang engan untuk memeriksa IMS karena tidak ada keluhan yang dialaminya ( FHI 1997 )

\section{Hubungan Karakteristik Pasien} dengan kejadian HIV pada wanita Usia subur

\section{a. Umur}

Hasil analisis dari sampel 312 orang wanita usia subur yang datang tes HIV di klini VCT UPT BLUD
Puskesmas Meninting, hasil analisa didapatkan 42 orang mengalami HIV positif dan kelompok terbanyak pada umur 20-35 tahun sebanyak 35 orang (11.2\%). Sedangkan dengan kejadian HIV negatif sebanyak 270 orang, dan kelompok terbanyak pada umur 20-35 tahun sebanyak 185 orang (59.3\%).

Berdasarkan Uji Chi-Square menunjukkan hasil $p$ volue $=0.018<$ 0.05, sehingga dapat disimpulkn bahwa, terdapat hubungan yang signifikan antara umur wanita usia subur dengan kejadian HIV.

Penelitian ini tidak sama dengan hasil penelitian Eulis Maratul tahun 2014, dimana hasil penelitian terbanyak terjadi HIV pada umur 20-24 tahun sebanyak 27 orang. Hasil Uji ChiSquare menunjukkan hasil $p$ volue $=$ $0.9>0.05$, sehingga dapat disimpulkan bahwa tidak terdapat hubungan yang signifikan antara umur dengan kejadian HIV.

Hal ini dikarenakan Umur yang muda menyebabkan mereka belum memikirkan efek dari penyakit HIV yang menyebabkan daya tahan menurun, dikarenakan masa terjadi transmisi dan penjalaran virus pada kurun waktu 5-10 tahun. Sehingga mereka belum memikirkan kondisi lain setelah mereka dinyatakan positif 
HIV, maka semakin berfikir ulang untuk melakukan setiap pemeriksaan ( Safitri, 2012 ).

Umur merupakan salah satu sifat karakteristik tentang orang yang dalam studi epidemiologi merupakan variabel yang cukup penting karena cukup banyak penyakit ditemukan dengan berbagai variasi frekuensi yang disebabkan oleh umur. Umur juga mempunyai hubungan yang erat dengan keterpaparan. Umur juga mempunyai hubungan dengan besarnya risiko pada penyakit tertentu, seperti halnya penyakit HIV/AIDS.

\section{b. Pendidikan}

Hasil analisis sampel wanita usia subur yang datang tes HIV dari 312 orang, hasil HIV positif sebanyak 42 orang dan HIV negatif sebanyak 270 orang dapat dilihat persentase terbanyak pada kelompok pasien dengan pendidikan SMP sebanyak 15 orang $(4.8 \%)$, sedangkan dengan kejadian HIV negatif sebanyak 116orang (37.2\%).

Berdasarkan Uji Chi-Square menunjukkan hasil $p$ volue $=0.011<$ 0.05, sehingga dapat disimpulkan, bahwa terdapat hubungan yang signifikan antara pendidikan wanita usia subur dengan kejadian HIV.

Penelitian ini sama dengan hasil penelitian Annisa (2014), tentang "Analisis Karakteristi dan FatorFaktor yang mempengaruhi Stigma Pengidap HIV (ODHIV) di Kota Yogyakarta. Dimanahasil penelitian terbanyak terjadi pada pendidikan sedang sebanyak $25.6 \%$ dengan hasil Uji Chi-Square menunjukkan hasil $p$ volue $=0.015>0.05$, sehingga dapat disimpulkan bahwa terdapat hubungan yang signifikan antara pendidikan dengan stigma pengidap HIV.

Pendidikan merupakan proses pengembangan kepribadian dan intelektual seseorang yang dilaksanakan secara sadar dan bertanggung jawab. Semakin tinggi tingkat pendidikan seseorang, biasanya tingkat pengetahuannya relatif baik sehingga gaya hidup dan perilakunya cenderung ke arah perilaku hidup sehat dan positif (Gobel, 2008).

Pendidikan berperan dalam tindakan yang akan dilakukan oleh seseorang termasuk dalam upaya pencegahan HIV/AIDS. Suatu studi yang perna dilakukan bahwa yang berpendidikan 
tinggi akan lebih rendah kerentanannya terhadap resiko penularan HIV/AIDS dibandingkan dengan mereka yang berpendidikan rendah maupun putus sekolah (Annisa. H, 2013)

\section{c. Pekerjaan}

Hasil analisis sampel wanita usia subur yang datang tes HIV sebanyak 312 orang, hasil HIV positif sebanyak 42 orang dan HIV negatif sebanyak 270 orang dapat dilihat persentase terbanyak pada kelompok pasien dengan pekerjaan tidak beresiko sebanyak 26 orang (8.3\%), sedangkan mengalami kejadian HIV negatif terbanyak pada kelompok pekerjaan tidak beresiko sebanyak 210 orang $(67.3 \%)$.

Berdasarkan hasil Uji Chi-Square menunjukkan hasil $p$ value $=0.026<$ 0.05, sehingga dapat disimpulkan bahwa, terdapat hubungan yang signifikan antara pekerjaan wanita usia subur dengan kejadian HIV.

Tetapi pekerjaan tidak bersiko lebih beresiko terkena penularan HIV/AIDS seperti pekerjaan ibu rumah tangga, penularannya berasal dari suami yang positif terkena HIV akibat sring be`rganti-ganti pasangan seks, atau sebalinya karena perempuan yang terkena HIV akibat sering bergantiganti pasangan seks.

Menurut penelitian yang dilakukan oleh Made Darmansyah (2013), tentang hubungan antara umur, pendidikan, dan pekerjaan istri dengan terjadinya HIV pada ibu hamil di Bali. Dimana hasil penelitian terbanyak pada pekerjaan tida beresiko sebanyak 23 orang, sedangkan pada pekerjaan beresiko sebanyak 2 org.

\section{d. Status perkawinan}

Hasil analisis smapel wanita usia subur yang datang tes HIV sebanyak 312 orang, hasil HIV positif sebanyak 42 orang dan HIV negatif sebanyak 270 orang dapat dilihat persentase terbanyak pada kelompok pasien dengan status kawin dan mengalami kejadian HIV positif sebanyak 23 orang $(7.4 \%)$, sedangkan dengan kejadian HIV negatif lebih besar sebanyak 232 orang $(74.4 \%)$.

Berdasarkan Uji Chi-Square menunjukkan hasil $p$ volue $=0.000<$ 0.05, sehingga dapat disimpulkn bahwa, terdapat hubungan yang signifikan antara status perkawinan wanita usia subur dengan kejadian HIV.

Penelitian ini sama dengan penelitian yang dilakukan Eulis (2014), tentang 
"Hubungan

Karakteristik

Pasien,Perilaku Beresiko Dan IMS

Dengan Kejadian HIV/AIDS Di

Puksemas Cikarang, Kecamatan

Cikarang Utara, Kabupaten Bekasi

Tahun 2013". Hasil penelitian uji

statistik menunjukkan ada hubungan

kejadian antar status perkawinan

dengan kejadian HIV. Nilai OR 8.1

dan 5.1 dapat diinpretasikan bahwa

pasien yang belum kawin memiliki kecendrungan untuk mengalami

kejadian HIV positif 8.1 kali lebih tinggi dibandikan status kawin (nilai $\mathrm{P}=0.000$ ). sedangkan pasien status cerai sebesar 5.1 kali lebih besar dengan kedain HIV positif pada status kawin (nilai $\mathrm{p}=0.006$ ).

Hasil ini berbeda dengan penelitian ini yang menunjukkan kejadian HIV pada satutus belum kawin dan cerai lebih besar dari status kawin sebanyak 23 orang.

Hal ini sejalan dengan beberapa penelitian lain, seperti yang dilakukan oleh Msuyaet al. (2006) di Tanzania, menunjukkan bahwa mereka yang tahu kalau pasangan mereka memiliki pasangan seks lain berisiko 15,11 kali untuk terinfeksi HIV dibanding dengan yang pasangannya memang tidak memiliki pasangan lain.
Penelitian lain oleh Gohs et al. (2011) di India, juga melaporkan bahwa perempuan yang pasangannya memiliki pasangan seks lain berisiko 3,40 kali untuk tertular HIV dibanding yang pasangannya tidak memiliki pasangan seks lain.

Status perkawinan menunjukkan apakah seseorang telah menikah atau belum menikah. Pernikahan Pada prinsip dasarnya adalah meningkatkan hubungan sesorang untuk lebih terikat. Keterikatan tersebut salah satunya dalam hubungan seksual yang berhubungan dengan fungsi reproduksi yaitu menghasilkan keturunan. Namun status perkawinan telah menikah terkadang lebih meningkatkan seseorang untuk berprilaku seksual dengan banyak pasangan.(Mandal,2008)

Perkawinan dan kesetiaan perempuan tidak cukup untuk melindungi mereka dari infeksi HIV di banyak negara. Contohnya Wilayah Zimbabwe, Durban dan Suweo ( Afrika Selatan) yang dilaporkan $66 \%$ populasinya hanya memiliki satu pasangan hidup, $79 \%$ tidak melakukan hubungan seks paling kurang sampai mereka berusia 17 tahun (kira-kira hampir sama dengan rata-rata hubungan seksual 
pertama di kebanyakan negara di dunia). Namun, $40 \%$ perempuan muda disana telah terinfeksi HIV meskipun mereka tetap setia dengan satu pasangan saja. Di kolumbia, 72 $\%$ perempuan dinyatakan positif terinfeksi HIV dan di India dilaporkan proporsi yang signifikan kasus baru adalah perempuan yang telah menikah dan terinfeksi oleh suami mereka yang sering melakukan hubungan seks komersial ( UNAIDS, 2005)

\section{Hubungan Perilaku Beresiko dengan Kejadian HIV pada Wanita} Usia Subur

Hasil analisis sampel wanita usia subur yang datang tes HIV sebanyak 312 orang, hasil HIV positif sebanyak 42 orang dan HIV negatif sebanyak 270 orang, persentase terbanyak pasien yang HIV negatif yang memilki perilaku beresiko pada kelompok pasien tidak melakukan sebanyak 125 orang $(40.1 \%)$ dan pasien yang mengalami HIV positif pada hubungaan seks tidak terlindungi sebanyak 19 orang $(6.1 \%)$.

Berdasarkan Uji Chi-Square menunjukkan hasil $p$ value $=0.000$ $<0.05$, sehingga dapat disimpulkan, bahwa terdapat hubungan yang signifikan antara perilaku beresiko wanita usia subur dengan kejadian HIV.

Pencegahan penyakit HIV-AIDS antara lain: Menghindari hubungan seksual denganngan penderita HIV-AIDS, mencegah berganti-ganti pasangan hubungan seksual, menghindari hubungan seksual dengan pecandu narkotika obat suntik, melarang orang berisiko tinggi untuk melakukan donor darah, memastikan sterilisasi alat suntik (Widoyono, 2011). Berdasarkan distribusi perilaku seksual berisiko dilihat dari kebiasaan responden menggunakan kondom, salah satu kegiatan penanggulangan HIV adalah mengupayakan peningkatan penggunaan kondom pada setiap kegiatan seks berisiko. Surve di banyak Negara menunjukkan semakin tinggi penggunaan kondom pada kegiatan seks berisiko mampu mencegah penularan HIV, terlihat dari semakin rendah kasus penularan infeksi menular seksual, termasuk HIV.

Hasil penelitian yang dilakukan oleh Niniek (2010), tentang Analisis Hubungan Pengetahuan Pencegahan HIV/AIDS Dan Prilaku Seks Tidak Aman pada Remaja 15-24 Tahun di Indonesia. hasil menunjukkan bahwa terbanyak pada kelompok prilaku seks tidak aman sebanyak $9.4 \%$ dan perilaku 
seks aman sebanyak 90.6\%. hasil uji statistic nilai $\mathrm{P}=0,000$, jadi kesimpulan terdapat hubungan yang bermakna antara prilaku seks tidak aman dengan remaja yang sikap terhadap penderita HIV/AIDS.

Dari hasil penelitian yang dilakukan oleh Irwan (2012), salah satu faktor tentang konsistensi penggunaan kondom oleh wanita pekerja seks/pelanggannya di Kota Semarang. responden yang pengetahuan yang tentang PMS dan HIV/AIDS yang tidak menggunakan kondom sebanyak $67,3 \%$, dan yang menggunakan kondom sebanyak 32.7\%. Dalam Uji nalitik menunjukkan hasil $p$ value $=$ $0.001<0.05$, sehingga dapat disimpulkan, bahwa terdapat hubungan faktor-fator dengan penggunaan kondom pada WPS/pelanggan.

Hal ini sesuai dengan teori bahwa kondom bisa mencegah terjadinya penularan penyakit HIV. Di mana semakin sering seseorang melakukan hubungan seksual selain dengan istri dengan tidak menggunakan kondom maka akan memberi peluang risiko tertularnya virus HIV lebih cepat.

Terkadang berbagai alasan digunakan untuk menolak memakai kondom ketika mereka berhubungandengan istri atau selain dengan istri. Pencegahan HIV dalam hubungan terletak pada laki-laki di mana penggunaan kondom lebih ditentukan oleh laki-laki.

\section{Hubungan Status IMS dengan Kejadian HIV pada Wanita Usia Subur}

Dari hasil analisis sampel wanita usa subur yang datang tes HIV sebanyak 312 orang, hasil HIV positif sebanyak 42 orang dan HIV negatif sebanyak 270 orang, persentase terbanyak pasien yang HIV positif yang termasuk dalam kelompok dengan beresiko pada kelompok pasien dengan status IMS sebanyak 26 orang $(8.3 \%)$, dan pasien yang mengalami kejadian HIV negatif terbanyak pada kelompok pasien tidak IMS sebanyak 156 orang (50.0\%).

Berdasarkan Uji Chi-Square menunjukkan hasil $p$ value $=0.017<0.05$, sehingga dapat disimpulkn bahwa, bahwa terdapat hubungan yang signifikan antara pendidikan wanita usia subur dengan kejadian HIV

Hasil penelitian sama dengan hasil penelitian yang dilakukan oleh Mar'atul (2014) dengan judul hubungan karakteristik pasien, perilaku beresiko dan IMS dengan kejadian HIV/AIDS di Puskesmas Cikarang, Kecamatan Cikarang Utara, Kabupaten Bekasi tahun 
2013. Menunjukkan hasil penelitian terdapat hubungan yang bermakna antara status IMS dengan kkejadian HIV/AIDS dengan hasil $P$ Value $=0.011$

Hubungan HIV/AIDS sangat erat karena IMS, terutama yang dengan lesi merupakan pintu masuk transmisi HIV melalui jalur seksual. Pasien yang tidak melakukan pemeriksaan IMS akan mempunyai resiko lebih tinggi untuk mengalami kejadian HIV positif dibandingkan dengan responden yang memeriksakan IMS. Ini dapat terjadi karena orang yang tidak memeriksa IMS tidak tahu bahwa kemingkinan mereka sebenarnya telah terinfeksi penyakit IMS sehingga melakukan perilaku beresiko tanpa mengaman yang pada akhirnya merugikan mereka karena bisa saja tertular HIV. Pelukaan pada kelamin karena adanya IMS dapat mempermudah seseorang HIV saat berhubungan seks tanpa pengaman.

\section{SIMPULAN}

Berdasarkan hasil analisis dan pembahasan diatas dapat disimpulkan sebagai berikut :

1. Terdsapat hubungan antara karakteristik pasien di Klinik VCT UPT BLUD Puskesmas Meninting Tahun 2015-2017 meliputi umur pada wanita usia subur dengan kejadian HIV, ( $p$ value $=0,018$ ), pendidikan pada wanita usia subur dengan kejadian HIV ( $p$ value $=0,002$ ), pekerjaan pada wanita usia subur dengan kejadian HIV ( $p$ value $=0,026$ ), status perkawinan pada wanita usia subur dengan kejadian HIV ( $p$ value $=0,000)$.

2. Terdsapat hubungan antara perilaku beresiko pada wanita usia subur dengan kejadian HIV di Klinik VCT UPT BLUD Puskesmas Meninting Tahun 2015-2017, sebanyak ( $p$ value $=0,000$ )

3. Terdsapat hubungan antara status IMS pada wanita usia subur dengan kejadian HIV di Klinik VCT UPT BLUD Puskesmas Meninting Tahun 20152017, sebanyak ( $p$ value $=0,017$ )

\section{DAFTAR RUJUKAN}

Andersen Brooks, R. 2014. A Behavioral Model Of Families Use Of Health Services. 25. Center For Health Administrasi Studies, Research Series. Diakses dari: www. Ssa.uchicago.edu.2014

A. Aziz. (2014). Metode Penelitian Kebidanan dan Teknik Analisis Data. Selembang Medika : Jakarta

Buku Register Klinik VCT Klinik VCT UPT BLUD Puskesmas Meninting Tahun 2015-2017, Provinsi NTB.

Dirjen PP dan PL.,(2008). Pedoman Pelayanan Konseling Dan Testing Secara Sukarela (Voluntary). 
Depkes RI., $2007 . \quad$ Komisi

Penanggulangan AIDS - Statistik

Kasus sampai dengan September 2007.

Data \& Profil Kesehatan RI. 2016. Laporan

Triwulan Situasi Perkembangan

HIV/AIDS di Indonesia 2016. Jakarta.

Data \& Profil Departemen Kesehatan. 2016.

Laporan HIV/AIDS diNTB2016.

Data profil Departem Keshatan Lombok Barat.(2016). Laporan Kasus

HIV/AIDS Lombok Barat 2016.

Dikes Lobar

Eulis Mar'atul Kamilah. 2014. Hubungan

Karakteristik Pasien, Prilaku beresiko,

dan Infeksi Menular Seksual Dengan

Kejadian HIV/AIDS di Klinik VCT

Puskesmas Cikarang tahun 203.

Bekasi. Fakultas Kesehatan

Masyarakat. Universitas Indonesia

H.M.S. Noer. 2014. Buku Ajar Ilmu

Penyakit Dalam Jilid 1 Edisi Ketiga.

Jakarta: Balai penerbit FKUI

Indonesian Business Coalition on AID,

2013. Development Jobs Indonesia. http://www.devjobs-

indonesia.blogspot.in. Diakses pada tanggal 21 Desember 2014

Kemenkes R.I (2012). Pedoman Nasional Pencegahan Penularan HIV dari Ibu ke Bayi. Jakarta: kementrian kesehatan RI
Mahubessy, Yunita. 2012. Konsep dasar HVI/AIDS.

http://yunitamahube.blogspot.com/20

12/11/normal-0-false-false-false-en-

us-X-none.html.Diakses hari Kamis tanggal 25 Desember 2014.

Muliana. (2016). Efidiomologi Penyakit Menular. Jakarta: Trans Info Media

Notoatmodjo, S., 2010. Metodologi Penelitian Kesehatan. Rhineka Cipta, Jakarta.

Notoatmojo, S. 1993. Pengantar Pendidikan Kesehatan dan ilmu perilaku kesehatan. Andi Offset: Jakarta

Nasrudin. 2007. Pengembangan Pengetahuan Penyakit Infeksi HIV Dan AIDS. Surabaya: AUP

Afrika, Nurhalina. (2012). Faktor-Faktor yang Berhubungan dengan Kejadian Infeksi Gonore pada Wanita penjaga Seks Komersial 16 Kabupaten. Depok:PKM UI

Simanjuntak, Erledis. 2010. Analisis Faktor Resiko Penularan HIV/AIDS di Kota Medan. Tesis Program Doktor Ilmu Lingkungan Di PPS UNSRI. Palembang

Sugiono.(2014). Etode Menelitian Pendidikan Pendekatan Kuantitatif, Kualintatif dan R\&D. Bandung:Alfabeta 
Sarwono.(2011). Psikologis remaja. Jakarta : PT Raja Grafindo Persada

Sarafino,E.P. (1994). Health Fisiology (2.Ed).New York: Willey

WHO. 2013. Global Summary Of The AIDS Epidemic.http://www.who.in/hiv/data. Diakses pada tanggal 21Desember 2014

Wold Health Organization. (2013). Pencegahan dan pengandalian infeksi. Geneva: WHO Press 